International Journal of English Literature and Social Sciences
Vol-6, Issue-6; Nov-Dec, 2021

Peer-Reviewed Journal

\title{
Exploring the Canon: Fontane's Effi Briest
}

\section{Sahib Kapoor}

Goethe Institute, New Delhi, India

Received: 03 Oct 2021; Received in revised form: 14 Nov 2021; Accepted: 21 Nov 2021; Available online: 03 Dec 2021

C2021 The Author(s). Published by Infogain Publication. This is an open access article under the CC BY license

(https://creativecommons.org/licenses/by/4.0/).

\begin{abstract}
Effi Briest is a celebrated work of realism and is considered the best novel of Theodor Fontane. Published back in 1894 the work still enjoys an important role in today's world. Effi Briest has joined the canon literature due to its highly controversial themes that are still relevant in today's world. This paper attempts to explore Fontane's masterpiece Effi Briest providing a thematic analysis of the novel and highlighting elements that led to the canonization of the novel.
\end{abstract}

Keywords-Bloom, Canon, Effi, Fontane, Huntgeburth.

\section{THE CANON}

The Canon, the word that has the power to permanently imprint the moral concepts of a society, has many aspects. The canon can be recognized under different terms, e.g. culture, everyday life, politics, literature. Hölter (2000) states that "canon makes culture". Canon is a collection of literary works that enjoy great popularity and have a normative meaning (Gfrereis, 1999). Throughout the world, numerous canons of literature prevail, be it continents like Europe or Asia or America or be it languages like German, Japanese or English. Over time, all societies in the world have established their culture-based canons to teach their people the social cultural values of their tradition. This trend of canonization is not a product of modernization, but dates back to the Middle Ages when the Bible was canonized to exert the power and authority of Christianity on the middle classes (Ulrich, 2002). But what is the significance of a canon today? Why do we actually need a canon? Who decides which literary works belong to canon and which do not? For whom is canon meant at all? What was the original purpose of the canon? How much reading is actually enough to understand oneself and one's own culture? There is no plausible answer to all these questions at the time, because all explanations only respond skeptically to the questions. Christa Jansohn doubts the role of the canon and quotes Frank Kermode "[C]anons are essentially strategic constructs by which societies maintain their own interest, since the canon allows control over the texts a culture takes seriously and over the methods of interpretation that establish the meaning of 'serious'"
(Jansohn, 2003).

Today, the word "canon" means a compiled reading list published by literary critics or quite a few cultural associations and organizations in order to bring their own culture-based way of thinking to light and thereby influence masses. But why mostly classical literature belongs to canon? In his essay 'Why Read Classics?" Italo Calvino (1991) explains the term thus; "Classics are those books that come laden with the traces of all the reading experiences that have preceded ours, trailing behind them the trail they have left in the culture or cultures (or simply in the language or customs) through which they have passed (Calvino, 2003). These classics are becoming required reading in universities and schools. They have become an indispensable part of the curriculum, making students oriented to and persistently aware of their culture and the history of their country. This is illuminatingly affirmed in the words of American literary scholar Harald Bloom: "Without the Canon, we cease to think." (Bloom, 1995). The literary critics are intensively studying the numerous authors and their works in order to highlight and issue a canon of literature, which serves as a guide and a basis for acquiring knowledge and intellectual development. In today's world, the canon has the function of a measuring device that questions the authenticity and literariness of a literary work. Questions of literary valuation and canon formation, however, have only come to light in literary studies since the 1950s. In his essay Literaturgeschichte als Provokation der Literaturwissenschaft (Literary History as a Provocation 
of Literary Studies), the Romance scholar Hans Robert Jauß stated that the previous canon of literature cannot claim validity: "For the quality and rank of a literary work derive neither from its biographical or historical conditions of origin nor solely from its place in the sequential relationship of the development of the genre, but from the elusive criteria of effect, reception and post-fame" (Jauß, 1970). Marcel Reich-Ranicki is considered Germany's most important literary critic. He has been called the pope of literature. He edited a fifty-volume collection of German literature entitled 'The Canon' from 2002 to 2006 (Ranicki, 2003). He was Germany's best known and most influential literary critic. His literary insights play a seminal role for young Germanists. His literary canon contains the power to give many students and researchers the sense of their studies. He triggered the current canon debate with his " Noah's Ark of Books" and an article in the ZEIT. In the ZEIT he published his reading list, which was highly criticized and is still an explosive topic. Reich-Ranicki's list includes the renowned novel Effi Briest by Theodor Fontane, which deals with the life of a woman, her divorce, and her social exile as a woman. The attempt of this article is to discuss the role of one of the most read books Effi Briest by Theodor Fontane in the German canon.

\section{FONTANE AND HIS MASTERPIECE}

Theodor Fontane was a German writer, journalist and critic who was born in Neuruppin on 30 December 1819. He is considered one of the main representatives of realism. Poetic realism is a literary movement from 1848 to the end of the 19th century. The works are dedicated to the social conditions in which a man finds himself. They become the central subject of the representation, and the authors focus only on the middle class and its economic conditions (Becker, 2003). Fontane is considered the first master of modern realistic fiction in Germany. He began his literary career in 1848 as a journalist and spent several years in England as a correspondent for two Prussian newspapers. In this position he wrote several books about English life, including A Summer in London (1854) and Beyond the Tweed (1860). In several of his novels Fontane deals with the problem of the role of women in domestic life; L'Adultera (1882); Die beim Ehebruch ertappte Frau), Irrungen, Wirrungen (1888), Frau Jenny Treibel (1893), and Effi Briest (1895) are among his best works. Effi Briest, in particular, is noted for its excellent characterization and skillful portrayal of the milieu of Fontane's native Brandenburg. Other major works include Der Stechlin (1899), distinguished by its charming style, and Schach von Wuthenow (1883); A Man of Honour), in which he depicts the foibles of the Prussian upper class. He died in Berlin on September 20, 1898. Theodor Fontane is today an author who is received throughout Europe. In most literatures into which texts by Fontane have been translated, Effi Briest holds a dominant position in the body of work: it is almost always the first, the best known, the most popular, and the most popular of all translations (Neuhaus, 2019). There are few languages where there is no translation of the novel at all. On this point, it is worth taking a look at the work.

Effi Briest is a sweeping work of poetic realism that appeared in six installments in the German Rundschau between October 1894 and March 1895 before being published as a book in 1896. The story revolves around a seventeen-year-old girl, Effi, who is married to Baron von Instetten for his good reputation. Readers experience Effi as a dynamic character who can endure anything but boredom. She is a soul who loves freedom and fun. After their marriage, the two move to Kessin, a small seaside town and Baron's home. On the carriage ride, Baron tells Effi about the Chinese haunting. Shortly after, Effi experiences the Chinese haunting herself and could not cope with it. Fontane writes in his letter to Josef Viktor Widmann on November 19, 1895, that the Chinaman was "a pivotal point for the whole story." As in this point, when Effi was restless, Baron despises Effi's anxiety and feelings and often leaves her alone because of his business trip. He was traveling a lot and could not understand Effi's anxiety and depth of feeling. Lacking Baron's lack of support and love, Effi cherishes the unsettling feelings. She ruminates on her husband's unkindness and indifference, that he didn't care if Effi was restless, terrified, or sleepless. Gradually, Effi no longer finds her husband a lover. She feels him more as "a man of character, position, and good manners." Shortly after this, the third character emerges, Major Crampas, a man who is well known in the town because of his notorious character. Major Crampas lures Effi by his tricks and the two begin a secret affair, giving Effi the spark of her life. She feels more and more free, relaxed and interested in these adventures. When Baron gets a job in Berlin, the two move to Berlin, which also brings the affair to an end. Effi and Baron find their way in Berlin and enjoy their life there. One day, however, Baron accidentally discovers Major Crampas's letters and learns of the secret love affair between his wife Effi and Major Crampas that he could never have suspected. Feeling betrayed, dishonored, and disappointed, he encourages Major Crampas to fight a duel. At the time, the duel was considered to be the only way to regain his honor and social status. In the duel, Major falls and dies. Baron wins and realizes his honor and social status in society again. However, he leaves his wife Effi and takes away his child. This allows the abandonment of Effi to be seen, as she now has no one to turn to and has to live alone in meager circumstances because the society including her parents have turned their backs on her. She cannot bear the 
loneliness and this excruciating pain for long and suffers from a fatal disease. Death comes as a redemption for Effi. On her last days, she experiences a bit of joy by moving to her home and staying with her parents. On these days, she admits that everything that has happened is owed to no one. Baron and Major Crampas are not to blamed. It is also evident from Effi's words that she did not love Major. He irritates her because he was brave, feisty, confident, and willing to take risks. She confesses that her husband was an honorable man and liked her a lot but she could not see this at that time. The novel ends with the sentence said by the father Briest "that is a wide field" when the mother Briest confronts him with the suspicion of having married Effi too young. The phrase points to the father's helplessness and his inability to contemplate because this is too complex for his understanding. The phrase runs like a thread through the story and has entered the German language. It is often quoted to communicate exactly these intentions.

The tragic end of Effi can be associated with the widely discussed role of women around the 19th century. According to Helmut Scheuer, Fontane wants Effi to be seen as a victim, thus emphasizing the social component of her fate (Scheuer, 2008). The role of women in society was often addressed. This trend is described by Elke Frederiksen in Die Frauenfrage in Deutschland as follows: "The situation of women, which had been accepted for thousands of years, first became a critically formulated "women's question" in the German Empire, and by the end of the 19th century it had increasingly become a decisive factor in social life (Frederiksen, 1994). One can perceive the circumstances of Effi with the commentary of Wolfgang Matz (2015). Matz in his book The Art of Adultery emphasizes; "An unfaithful husband still remains a husband, but an unfaithful wife remains nothing at all" (Wolfgang, 2015). This can also be seen as an important feature of the downfall of Effi. The beginning of Effi's love affair can be seen as a step into empty space, which is her own fault. She is a victim of her indomitable urges and must pay the debt for the rest of her painful lonely life.

The novel can also be identified with Madame Bovary by Gustave Flaubert to a certain extent because both protagonists, be it Effi, or Emma despised the surrounding society and made up their minds to go their own way. In Madame Bovary, the protagonists, like Effi, has a husband whom she does not particularly love. Effi and Emma suffer from the same problem: attractive young women stuck in provincial European towns, married to boring husbands, to whom Paris and Berlin offer a glimpse of a different life. Dancing, dinner parties, coquetry, perfume, department stores, boulevards, billet-doux... they enjoy it all until a cad comes along, the seductive but unprincipled lover who sweeps them away. These affairs have disastrous consequences. Unlike Effi, Emma commits suicide because she could not stop themselves, whereas Effi dies but of an illness. However, one can infer that the cause of her death is her unhappiness over her lost life. What is strange in the two novels is that a woman's desire to go her own way leads to her downfall and is followed by her banishment from society and her death. The portrayal of free urges play a significant role in the novel Effi Briest, as these urges cause her pain, in that her marriage fails when her husband finds out about her affair with Major Crampas. She is neglected and despised by her husband and society and has to alienate herself from both. His husband "Baron" bears responsibility for the care of the child and the child is brought up without maternal care, as a result of which the child has no mother-daughter bond and no compassion for her mother. Accordingly, Effi feels absolutely nothing and feels inner emptiness.

Effi Briest has been adapted many times. The adaptations are Der Schritt vom Wege (1938/39) by Gustaf Gründgens, Rosen im Herbst (1955) by Rudolf Jugert, Effi Briest (1968/69) by Wolfgang Luderer, Fontane Effi Briest (1972-1974) by Rainer Werner Fassbinder and Effi Briest (2007-2009) by Hermine Huntgeburth. The latest film adaptation is by Hermine Huntgeburth, which premiered at the Berlinale (IFF) on February 9, 2009 and subsequently appeared in cinemas across Germany. "This latest film adaptation also begins with Effi as a "daughter of the air," but Hermine Huntgeburth tells Fontane's novel as a 'coming-of-age' story, because it is primarily about Effi growing from a pubescent girl into an independent and mature woman. It is thus a kind of emancipation narrative that includes sexual liberation but does not allow it to become central " (Neuhaus, 2019). The film stands out particularly as an emancipation story, the story of a young woman discovering her passion, her sexuality and her individuality. The love scene between Crampas and Effi is the indication of Effi becoming aware of her individuality. Thanks to the explosive unusual themes such as the Chinese haunting, self-discovery or the failure of marriage and its consequences in a woman's life, Fontane's work has retained its relevance to the present day, thus proving to be a classic. The story enjoys ever-increasing popularity and this is the reason that it is widely received and belongs to the canon of German literature.

\section{CONCLUSION}

Thanks to controversial themes such as selfdiscovery or the failure of marriage and its consequences in a woman's life, Fontane's work has retained its relevance to the present day, thus proving to be a classic. The story enjoys ever-increasing popularity and this is the reason that it is widely received and belongs to the canon of German 
literature. The work is quite important in today's society since it questions the role of women throughout history. Effi represents women, who are the victim of society and the only crime they commit is to follow the instinct and step out of their conventional role. Effi Briest is more than 100 years old but is still quite relevant and carries an important message to accept women as a part of society regardless of their preferences and decisions.

\section{REFERENCES}

[1] Becker, Sabine (2003): Bürgerlicher Realismus; Literatur und Kultur im bürgerlichen Zeitalter 1848-1900. Tübingen: Francke.

[2] Bloom, Herald (1995). The Western canon: The books and school of the ages. New York: Penguin

[3] Craig, Gordon (1999). Theodor Fontane: Literature and History in the Bismarck Reich, New York: Oxford University.

[4] Degering, Thomas (1978). Das Verhältnis Von Individuum Und Gesellschaft In Fontanes "effi Briest" Und Flaubert's "madame Bovary". 1st ed. Bonn: Bouvier.

[5] Fontane, Theodor (1967). Effi Briest. Harmondsworth, Middlesex: Penguin Books.

[6] Fontane, Theodor (2009). Meine Kinderjahre. ein autobiografischer Roman von 1892, Norderstedt Grin Publishing

[7] Glaser, Hors (1992).: Theodor Fontane: Effi Briest. In: Interpretations: Novels of the 19th century. Stuttgart [u. ö.] (UB. 4818.) pp. 387-415.

[8] Grawe, Christian (1996): Führer durch Fontane's Romane. Ein Lexikon der Personen, Schauplätze und Kunstwerke. Stuttgart [u. ö.].

[9] Hage, Volker and Saltzwedel, Johannes (2001). Noah's Ark of Books. In: Der Spiegel. No. 25, pp. 206-210

[10] Hamann, Elisabeth: Theodor Fontane Effi Briest. Munich 1979. (Oldenbourg Interpretations.) Reisner, Hanns-Peter / Rainer Siegle: Stundenblätter Effi Briest. Stuttgart.

[11] Hölter, Achim. "R. von Heydebrand (ed.)( 1999), Kanon Macht - Kultur. Theoretical, historical and social aspects of aesthetic canon formations. (Germanistische Symposien Berichtsbände 19)/: ", vol. 18, no. 2, Press.

[12] Jauß, Hans Robert (1970): Literaturgeschichte als Provokation der Literaturwissenschaft. In: Ders.: Literaturgeschichte als Provokation. Frankfurt a. M. pp 144-207

[13] Matz, Wolfgang (2015), Die Kunst des Ehebruchs - Emma, Anna, Effi und ihre Männer. Wallstein, Göttingen.

[14] Mecklenburg, Norbert(1998). Theodor Fontane. Romance art of polyphony. Frankfurt a. Main.

[15] Neuhaus, Stefan (2019). Effi Briest: Handbook. J.B. Metzler Verlag, Berlin

[16] Ulrich, Eugene. (2002) The notion and definition of canon. In McDonald, L. M.; Sanders, J. A. (eds.). The Canon Debate. Hendrickson Publishers.

[17] Wittstock, Uwe (2015). Marcel Reich-Ranicki: The biography. Munich 